\title{
THE EFFECT OF GAMMA IRRADIATION OF THE VOLATILITY AND REDOX STATE OF SIMULATED DWPF HIGH-LEVEL NUCLEAR WASTE GLASSES (U)
}

\author{
by J.R. Harbour
}

Westinghouse Savannah River Company

Savannah River Site

Aiken, South Carolina 29808

WSRC-MS--93-015

Other Authors:

\section{J. C. Marra}

N'SRC)

N. E. Bibler

(WSRC)

A paper proposed for Presentation/Publication

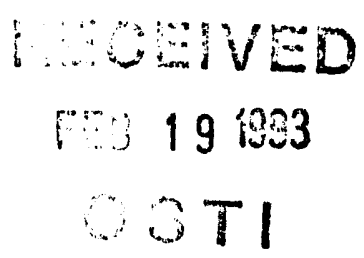

at/in the International High Level Radioactive Waste Management Conference

Las Vegas, NV

04/25-30/93

This paper was prepared in connection with work done under Contract No. DE-AC09-89SR18035 with the U. S. Department of Energy. By acceptance of this paper, the publisher and/or recipient acknowledges the U. S. $G$ ernment's right to retain a nonexclusive, royalty-free license in and to any copyright covering this paper, along with the right to reproduce and to authorize others to reproduce all or part of the copyrighted paper.

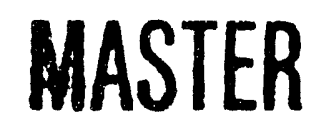




\section{DISCLAIMER}

This report was prepared as an account of work sponsored by an agency of the United States Government. Neither the United States Government nor any agency thereof, nor any of their employees, makes any warranty, express or implied, or assumes any legal liability or responsibility for the accuracy, completeness, or usefulness of any information, apparatus, product, or process disclosed, or represents that its use would not infringe privately owned rights. Reference herein to any specific commercial product, process, or service by trade name, trademark, manufacturer, or otherwise does not necessarily constitute or imply its endorsement, recommendation, or favoring by the United States Government or any agency thereof. The views and opinions of authors expressed herein do not necessarily state or reflect those of the United States Government or any agency thereof.

This report has been reproduced directly from the best available copy.

Available to DOE and DOE contractors from the Office of Scientific and Technical Information, P. O. Box 62, Oak Ridge, TN 37831; prices available from (615) $576-8401$.

Available to the public from the National Technical Information Service, U. S. Department of Commerce, 5285 Port Royal Rd., Springfield, VA 22161. 
WESTINGHOUSE SAVANNAH RIVER COMPANY SAVANNAB RIVER TECENOLOGY CENTER

WSRC-MS-93-015
ReVision 0

KEY WORDS: TGA, DSC

Retention: Permanent

January 11, 1993

TO: $\quad$ M. J. PLODINEC

FROM: J. R. HARBOUR, J. C. MARRA, AND N. E. BIBLER

TEE EFFECT OF GAMMA IRRADIATION ON TEE VOLATIIITY AND REDOX STATE OF SIMOIATED DWPE BIGE-IEVEL NUCIEAR MASTE GLASSES (U) 


\title{
THE EFFECT OF GAMMA IRRADIATION ON \\ THE VOLATILITY AND REDOX STATE OF SIMULATED DWPF HIGH.LEVEL NUCLEAR WASTE GLASSES
}

\author{
J. R. Harbour, J. C. Marra and N. E. Bibler \\ Savannah River Technology Center \\ Westinghouse Savannah River Company \\ Aiken, South Carolina 29808 \\ (803) 725.8725
}

\begin{abstract}
Gamma-induced volatility of simulated 'DWPF high-level nuclear waste glasses is highly dependent upon the redox state of the glass. For oxidized glasses with an $\mathrm{Fe}^{2+} /\left(\mathrm{Fe}^{2+}+\mathrm{Fe}^{3+}\right)$ ratio $<0.1$, no volatility was detected after gamma irradiation. Since the projected DWPF high-level radioactive waste glasies will be oxidized, no significant gamma-inriuced volatility is expected for these glasses up 0 the glass transition temperature. For larger pieces of highly-reduced DWPF simulated waste glass, no volatility was observed (using $\sim 100 \mathrm{mg}$ pieces in the TGA) a.ter gamma irradiation. However, for powdered samples of this reduced glass, volatility changes upon gamma radiation were detected at 350 and $475^{\circ} \mathrm{C}$. The volatility at $350^{\circ} \mathrm{C}$ was due to changes at the glass surface whereas the changes in volatility at $475^{\circ} \mathrm{C}$ were due to interactions of gamma irradiation within the bulk of the glass. The glass transition temperatures of both oxidized and reduced glasses were unaffected by gamma irradiation but did increase upon a second heat cycle. Results are also presented which reveal that no significant change in redox level within the glass occurred as a result of gamma irradiation.
\end{abstract}

\section{INTRODUCTION}

The Defense Waste Processing Facility (DWPF) will immobilize Savannah River Site's high-level nuclear waste, currently stored in underground carbon steel tanks, by incorporating radionuclides irto a glass matrix. The molten waste glass will be poured into stainless steel canisters which, after cooling, will be welded shut to produce the canistered waste forms. The DOE has issued the Waste Acceptance Preliminary Specifications'(WAPS) which must be met prior to shipment of these canistered waste forms to a Federal Repository. One of these specifications requires that any volatiles produced as a result of accidently heating the waste glass to the glass transition temperature, be identified. The rationale for identifying volatiles is to ensure that they are compatible with the stainless steel, and are not foreign materials as defined in the WAPS.

It has been previously demonstrated 2 that no detectable volatiles are produced when simulated high-level waste glass is heated to the region of the glass transition temperature $\left(-450^{\circ} \mathrm{C}\right)$. The detection limit of the thermogravimetric analyzer used was 0.01 wt \% by mass, and $330 \mu \mathrm{g} / \mathrm{m}^{2}$ by glass surface area. Oxygen uptake was cbserved in reduced glasses (glasses containing appreciable amounts of $\mathrm{Fe}^{2+}$ ) due to oxidation of $\mathrm{FeO}$ to $\mathrm{Fe}_{2} \mathrm{O}_{3}$. The weight gain was as high as $0.6 \%$ by weight $(600 \mu \mathrm{g}$ in $100 \mathrm{mg}$ of glass).

During radioactive operations, the waste glass will contain radionuclides that produce a radiation field within the glass. This radiation field has the potential to change the volatility 
and redox state (measured by the $\mathrm{Fe}^{2+}$ content) of the waste glass. This paper addresses the effect of gamma irradiation on these two properties of the waste glass. Gamma rays interact with matter primarily by the photo. electric effect and Compton scattering, processes which result in secondary electron production. Hence, this study also determines the effect of beta radiation on the glass. The effect of alpha and neutron interactions will be dealt with separately.

\section{EXPERIMENTAL}

\section{Glass Composition}

Results are presented for two glasses in this paper. They are a highly reduced glass, Sample 7-8, and a highly oxidized glass, Sample 1-03. The $\mathrm{Fe}^{2+} /\left(\mathrm{Fe}^{2+}+\mathrm{Fe}^{3+}\right)$ ratio reflects the redox level of the glass and is 0.63 for sample $7-8$ and 0.09 for sample 1-03. These glasses are sodium borosilicate glasses containing simulated high level radioactive waste 2.3 . The main elements in the simulated waste are $\mathrm{Fe}$ and $\mathrm{Al}$ along with lesser amounts of $\mathrm{Ca}, \mathrm{Mn}$, and $\mathrm{Mg}$.

\section{Particle size}

Both glass pieces ( 5mm) and glass powders (-200 mesh) were used in this study. The glass powders were created by milling the larger glass pieces using a mechanical grinder (Tekmar Grinding Mill with a tungsten carbide blade) and then collecting only those particles which passed through a 200 mesh screen. Glass pieces, which weighed approximately $100 \mathrm{mg}$ each, were fragments obtained from larger pieces.

\section{Gamma Radiasion.}

To simulate conditions of years of irradiation by gamma rays, non-radioactive, simulated waste glasses were subjected to doses from a cobalt-60 source. The design basis glass contains $4.3 \times 10^{4}$ curies/canister of cesium-137, the major source of gamma flux within the canister. This corresponds to a dose rate of approximately $5000 \mathrm{rads} /$ hour or $4.4 \times 10^{7} \mathrm{rads} / \mathrm{year}$. The two exposures from the cobalt-60 source were $10^{8}$ and $10^{9}$ rads which corresponds to roughly 2 and 25 years of storage respectively. The irradiations were carried out in air on both large pieces and glass powder (-200 mesh).

\section{TGA measurements}

Thermogravimetric Analysis (TGA) is a technique which measures weight changes in samples was a function of temperature. TGA experiments were carried out using a TA Instruments 951 Thermogravimetric Analyzer and 2100 Thermal Analyzer. Samples (-70 $\mathrm{mg}$ for powder and $-100 \mathrm{mg}$ for pieces) were placed in platinum boats. The purge gas was air. The flow rate was typically $50 \mathrm{ml} / \mathrm{min}$. Calcium oxalate monohydrate from TA Instruments was used as the "standard" for the TGA experiments.

The samples of simulated waste glass were subjected to two different cyclic profiles. In the cyclic profile referred to as profile $\# 1$, the sample is heated to $450^{\circ} \mathrm{C}$ at a rate of $10^{\circ} \mathrm{C} /$ minute. It is held at $450^{\circ} \mathrm{C}$ for 10 minutes and then slowly ramped at a rate of $0.50 \mathrm{C} /$ minute to $500^{\circ} \mathrm{C}$. After a 10 minute holding period at $500^{\circ} \mathrm{C}$, the sample is cooled to room temperature using the reverse of the profile used for sample heating.

In cyclic profile $\$ 2$, the sample was heated to $325^{\circ} \mathrm{C}$ at $10^{\circ} \mathrm{C} /$ minute, then raised from $325^{\circ} \mathrm{C}$ to $375^{\circ} \mathrm{C}$ at a rate of $0.5^{\circ} \mathrm{C} /$ minute, and then heated to $500^{\circ} \mathrm{C}$ at $10^{\circ} \mathrm{C} /$ minute. After a ten minute hold at $500^{\circ} \mathrm{C}$, the sample was cooled using the same heat profile.

\section{DSC measurements}

Differential scanning calorimetry (DSC) experiments provided a measurement of the glass transition temperature $\left(T_{g}\right)$. These tests were conducted using a TA Instruments 910 differential scanning calorimeter and a 2100 thermal analyzer with an air flow rate of 50 $\mathrm{ml} / \mathrm{min}$. Samples, contained in open aluminum pans, were heated at $10^{\circ} \mathrm{C} / \mathrm{min}$ to $550{ }^{\circ} \mathrm{C}$, held for one minute an then cooled at $10^{\circ} \mathrm{C} / \mathrm{min}$. Zinc (melting point) was used as the "standard" for DSC experiments.

In several TGA and DSC experiments the heating cycles were repeated on the same sample. These tests were conducted to examine the reversibility of any changes following initial heating. 


\section{Redox measurements.}

The $\mathrm{Fe}^{2+} / \mathrm{Fe}^{3+}$ ratios were determined colorimetrically after dissolution of the glass using the prosedure developed by Baumann ${ }^{4}$. The experiments were performed using a Hewlett-Packard 8451 Diode Array Spectrophotometer.

\section{RESULTS AND DISCUSSION}

Measurement of $\mathrm{Tg}$ - Effect of Gamma_Iradiation and Heat Recrcle

The WAPS requires that volatility be determined up to the glass transition temperature, $T_{g}$. We therefore measured $T_{g}$ for both these samples using the technique of DSC.

The glass transition temperature, $T_{\boldsymbol{g}}$, was measured from the DSC data as the intersection of the tangent lines as illustrated in Figure 1. The samples were subjected to repeated heat cycles until no further changes in $T_{g}$ were observed. The value of $T_{8}$ increased from $443^{\circ} \mathrm{C}$ in the first cycle to $465^{\circ} \mathrm{C}$ in the second cycle for sample 7.8 (Figure la). No further changes were observed when the sample was subjected to a third cycle. For sample $1-03$, the $T_{g}$ increased from 447 to $457^{\circ} \mathrm{C}$ in the first two cycles and remained at $457^{\circ} \mathrm{C}$ in the third cycle.

This change in $T_{g}$ from the first to second cycle may reflect stress release during the first cycle for the unannealed glass. In any event, the values of $T_{g}$ are close to $4500 \mathrm{C}$, and below the $500^{\circ} \mathrm{C}$ upper limit of both TGA profiles

It is interesting to note that no changes in $T_{g}$ occurred upon exposure of either sample to $10^{9}$ rads of gamma irradiation. That is, the measured yalues of $T_{g}$ were independent of gamma irradiation. The changes noted in the DSC curves upon gamms irradiation (Figure 1b) will be discussed below.

\section{Effect of Gamma Imadiation - TGA Resulks Oxidized Glass (Sample 1-03)}

For the oxidized glass, no significant weight gain or loss was observed with TGA. Gamma irradiation of these glasses, as either powders or large pieces, had no effect on either the TGA or the DSC results. In the case of this highly

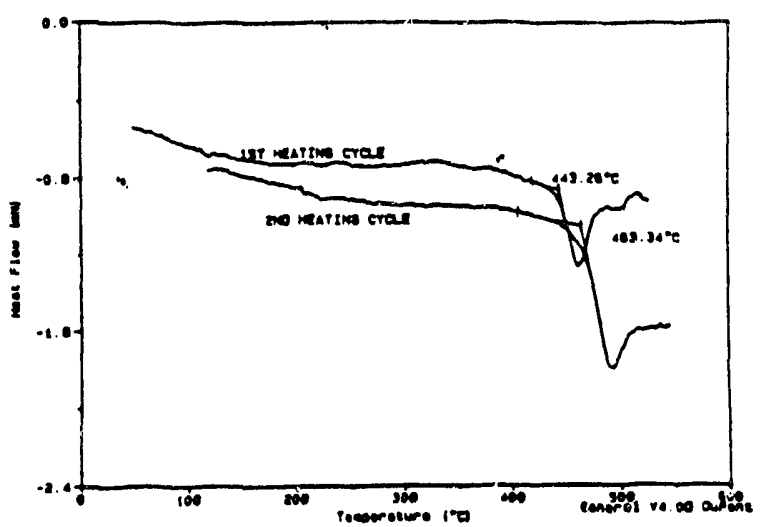

(a)

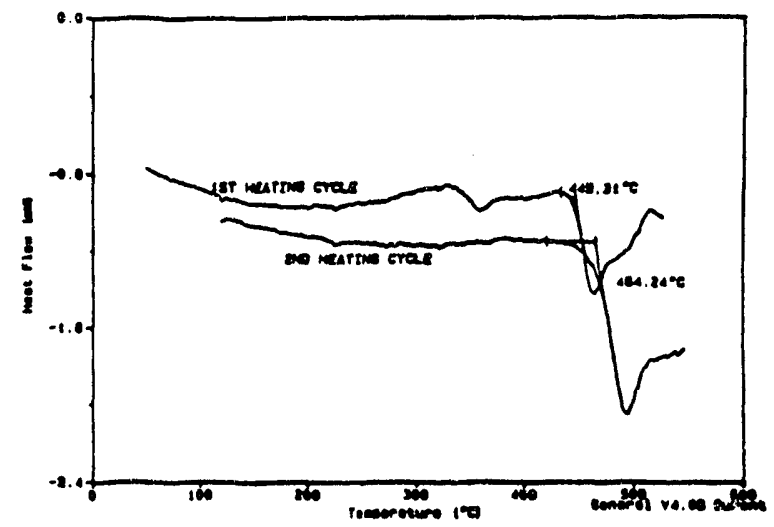

(b)

Figure 1. Differential scanning calorimerry curves of sample $7-8$ powder (a) before irradiation and (b) after $10^{9}$ rads gamma irradiation. Heating cycle was repeated on each sample.

oxidized glass, most of the $\mathrm{Fe}$ is present as $\mathrm{Fe}^{3+}$ and oxygen uptake is therefore negligible. Hence gamma irradiation of oxidized glasses within the canistered waste form will not result in any volatility to the sensitivity of the TGA for the glass when heated to $T_{g}$. This corresponds to a surface volatility (based on a previous analysis ${ }^{2}$ ) within the canister below 0.048 total mass. The DWPF glasses will be oxidized with the requirement that $\mathrm{Fe}^{2+} /\left(\mathrm{Fe}^{2+}+\mathrm{Fe}^{3+}\right)<0.3$. It is currently anticipated that this ratio may have a maximum value of 0.1 . 


\section{Effect of Gamma Irradiation - TGA Resulss Reduced Glass (Samole 7-8)}

Figure 2 a demonstrates that powdered 7.8 glass gains weight as it is heated in the presence of air. After the powdered glass was gamma irradiated, the glass still gains weight as it is heated; however some changes in the TGA curves were evident. Figure $2 b$ and $2 c$ show these curves after irradiation of $-10^{8}$ and $-10^{9}$ rads. Volatility is now evident at approximately $350^{\circ} \mathrm{C}$ and $475^{\circ} \mathrm{C}$ and apparently increases with dose. F-producibility of these changes in TGA upon gamma irsadiation was demonstrated with at least seven different samples of 7.8 glass.

The DSC curve in Figure 1b reveals that endothermic peaks had developed at both these temperature regions after gamma irradiation. This is consistent with the TGA results and shows that heat is being absorbed by the sample at the point of volatility. The TGA shows no further change and the DSC no longer indicates heat absorption at these two temperatures upon exposure to a second heat cycle. This implies that the changes in the glass as a result of gamma irradiation, are removed upon subjecting the glass to the first cyclic profile.

\section{Effect of Particle Size}

No changes occur up to $500^{\circ} \mathrm{C}$ on the TGA for larger pieces of glass $(-100 \mathrm{mg})$ either before or after gamma irradiation (Figure 3), If an irradiated piece is ground, and then measured by TGA, no volatility at $350^{\circ} \mathrm{C}$ is observed. However, the volatility at $475^{\circ} \mathrm{C}$ is now evident. This suggests that the volatility at $350^{\circ} \mathrm{C}$ is of surface origin whereas the volatility change at $475^{\circ} \mathrm{C}$ originates within the bulk of the glass.

\section{Volatility at $350^{\circ} \mathrm{C}$}

This gamma-induced volatility at $350^{\circ} \mathrm{C}$ corresponds to a weight loss of 0.025 wt\% after $10^{9}$ rads exposure. This is an approximate weight loss due to the fact that in this region. oxygen uptake is also occurring resulting in a concomittant weights gain. The fact that this volatility is only observed after gamme irradiation of powdered samples, implies that the site for this volatility is at the glass surface. The volatile species has not been identified, but is most likely water or oxygen.

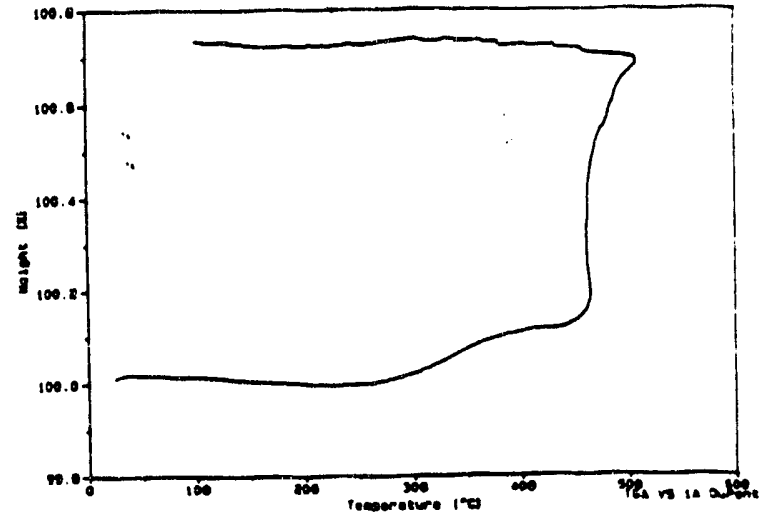

(a)

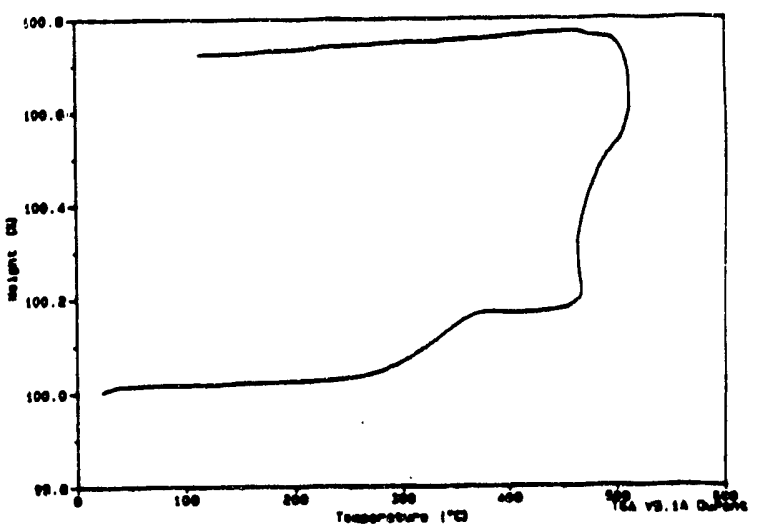

(b)

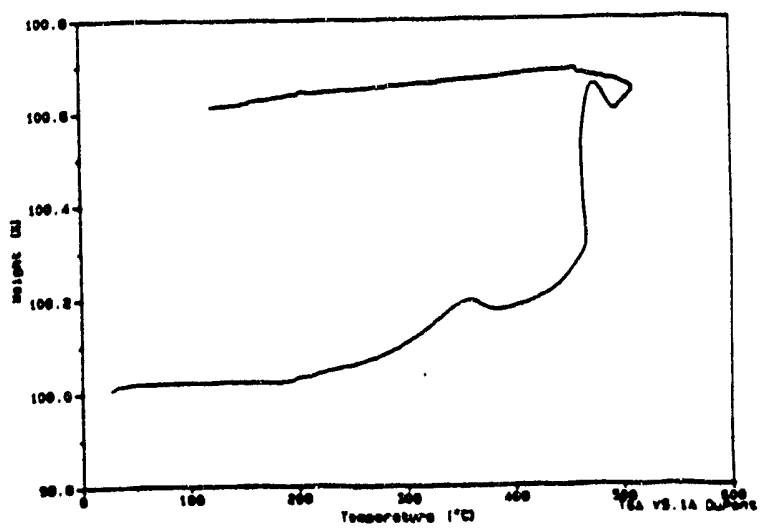

(c)

Figure 2. TGA curve.. using profile 1 for sample 7.8 powder (a) before irradiation, (b) after $10^{8}$ rads gamma irradiation, and (c) after $10^{9}$ rads gamma irradiation. 


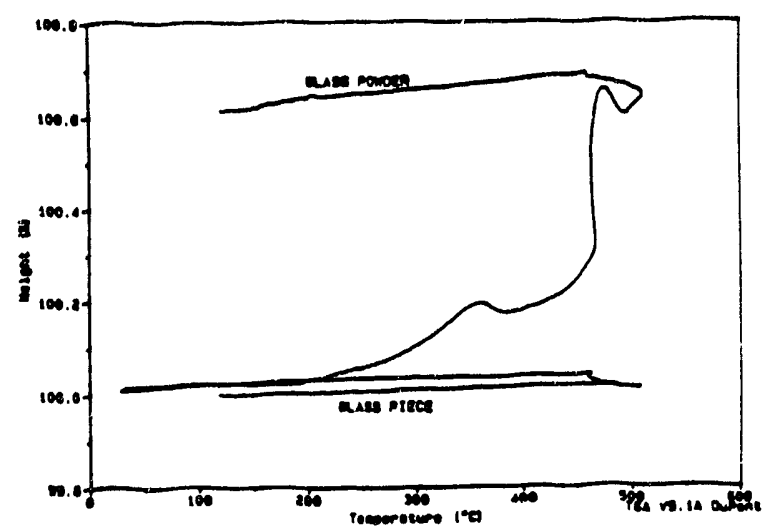

Figure 3. TGA curves using profile 1 for sample 7-8 glass powder and a sample 7-8 glass piece.

This small amount of volatility translates to $-100 \mathrm{mg}$ of volatiles per canistered waste form after $10^{9}$ rads exposure and an accidental increase in temperature up to $350^{\circ} \mathrm{C}^{2}$. However, this glass is much more reduced than projected for DWPF radioactive waste glass, and therefore this value is a very conservative upper limit of volatility.

\section{Volatility at $475^{\circ} \mathrm{C}$}

The use of profile $* 2$ for the TGA experiments revealed that volatility at $475^{\circ} \mathrm{C}$ is present even in unirradiated, reduced powders. Figure 4 shows the changes which occur in this region upon increased gamma irradiation. The effect of gamma irradiation was to shift the onset of volatility to greater temperatures and to narrow the region over which the volatility occurred. This effect accentuated the loss at $475^{\circ} \mathrm{C}$ after gamma irradiation using profile \# 1 (see Figure 2).

The weight loss at $475^{\circ} \mathrm{C}$ approaches $0.2 \mathrm{wt} \%$. This type of weight loss occurs with both the unirradiated and irradiated glass. The source of the volatility probably originates in the bulk since irradiation of large glass pieces gave rise to this volatility after grinding the pieces to -200 mesh. The source of this volatility has not been identified. Further work is in progress to indentify the volatile species.

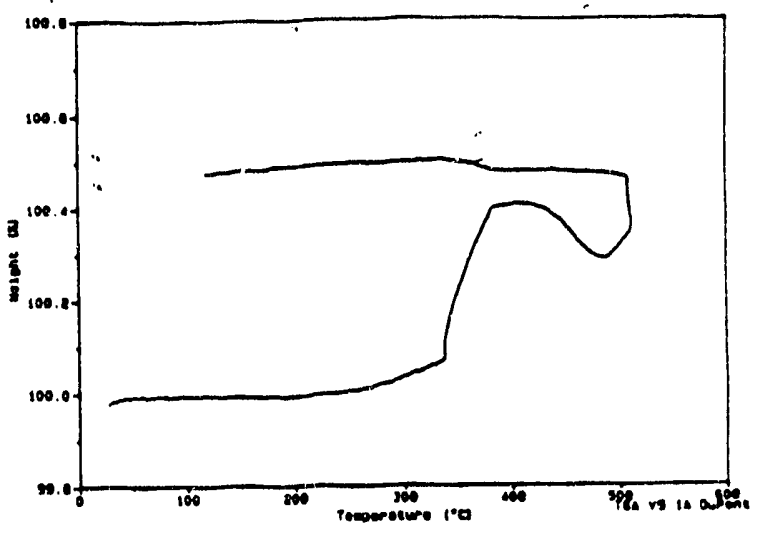

(a)

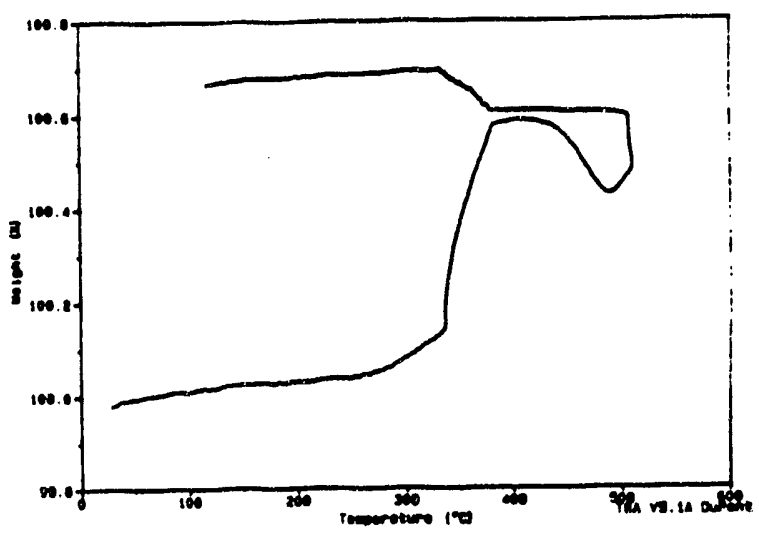

(b)

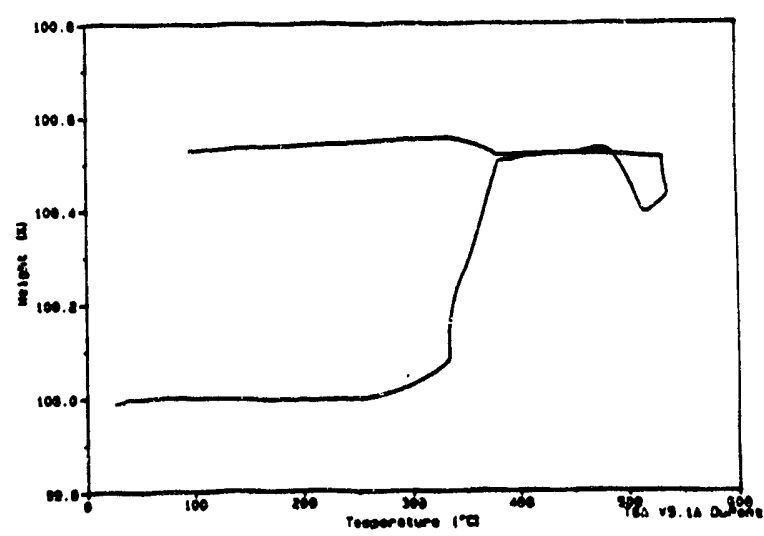

(c)

Figure 4. TGA curves using profile 2 for sample 7.8 powder (a) before irradiation, (b) after $10^{8}$ rads gamma irradiation, and (c) after $10^{9}$ rads gamma irradiation. 


\section{Effect of gamma imadiation on redex}

The results of these experiments reveal that gamma irradiation does not significantly alter the redox state of the glass. The redox state within the glass is reflected mainly from the ratio of $\mathrm{Fe}^{2+} /\left(\mathrm{Fe}^{2+}+\mathrm{Fe}^{3+}\right)$. The TGA results demonstrate that overall oxygen uptake is not significantly altered after gamma irradiation indicating no significant change in the $\mathrm{Fe}^{2+}$ or $\mathrm{Fe}^{3+}$ content of the glass.

Similar results have been obtained from dissolution measurements of the $\mathrm{Fe}^{2+} /\left(\mathrm{Fe}^{2+}\right.$ $+\mathrm{Fe}^{3+}$ ) ratio. For example, for the highly reduced glass, the redox ratio determined colorimetically was 0.63 indicating that most of the $\mathrm{Fe}$ was in the +2 state. After irradiation to a dose of $10^{9}$ rads, dissolution and analysis of two samples of the glass gave a redox ratio of $0.63 \pm$ 0.07 in agreement with the ratio for the unirradiated glass. These results are consistent with the TGA results and indicate that redox state of the glass is not changing as a result of gamma irradiation.

\section{CONCLUSIONS}

Gamma irradiation of either powdered or large pieces of oxidized, DWPF simulated waste glass results in no detectable volatility to the detection limit of the TGA instrument. This implies that the radiation field of gamma and beta irradiation will not lead to significant volatility within canistered waste forms as long as the radioactive waste glass is oxidized. In fact, the DWPF has imposed an upper limit on the $\mathrm{Fe}^{2+} /\left(\mathrm{Fe}^{2+}+\mathrm{Fe}^{3+}\right)$ ratio of 0.3 which reflects a fairly highly oxidized glass.

On the other extreme, gamma irradiation of powdered, highly reduced glass does affect the volatility of the glass at both $350^{\circ} \mathrm{C}$ and $475^{\circ} \mathrm{C}$. At $350^{\circ} \mathrm{C}$ volatility is obseried as a result of gamma irradiation. The volatile species is most likely water or oxygen. However, the amount of volatility observed, $0.025 \mathrm{wt} \%$, is not significant. Volatility at $350^{\circ} \mathrm{C}$ was not observed when the glass was irradiated as a large piece rather than a powder suggesting that the volatility resulted from a radiation induced reaction on the surface of the glass.
Gamma irradiation of reduced glass also affected the volatility at $475^{\circ} \mathrm{C}$. Radiation caused the volatility at $475^{\circ} \mathrm{C}$ to shift to a higher temperature and narrowed the temperature"range for the volatility. The source of this volatility is unknown, but efforts are underway to identify the volatiles.

These two glasses give us the two extremes of redox state. Additional work is in progress on glasses having intermediate redox levels. However, the upper limit of redox level imposed on DWPF waste glass, indicates that the radioactive waste glasses will be much closer to the highly oxidized glass. This in turn implies that volatility from gamma and beta radiation within the canistered waste form will not lead to significant volatility.

Finally, these results have shown that, based on the amount of $\mathrm{Fe}^{+2}$ in the glass, the redox level of the glass is not affected by gamma radiation.

\section{REFERENCES}

1. "Waste Acceptance Preliminary Specifications for Vitrified High-Level Waste Forms," DRAFT, (1991).

2. J. R. HARBOUR, "Volatility of Simulated High-Level Nuclear Waste Glass by Thermogravimetric Analysis," L_Am_Ceram._Soc. 25. 507 (1992).

3. N. E. BIBLER, J. P. BIBLER, M. K. ANDREWS, and C. M. JANTZEN, "Initial Demonstration of the Vitrification of High-Level Nuclear Waste Sludge Containing an Organic Cs-Loaded Ion Exchange Resin", WSRC-MS-91-465, Westinghouse Savannah River Site (1992).

4. C. J. COLEMAN, E. W, BAUMANN, and N. E. BIBLER, "Colorimetric Determination of $\mathrm{Fe}$ (II)/Fe(III) Ratio in Radioactive Glasses", Proceedings of the International High-Level 

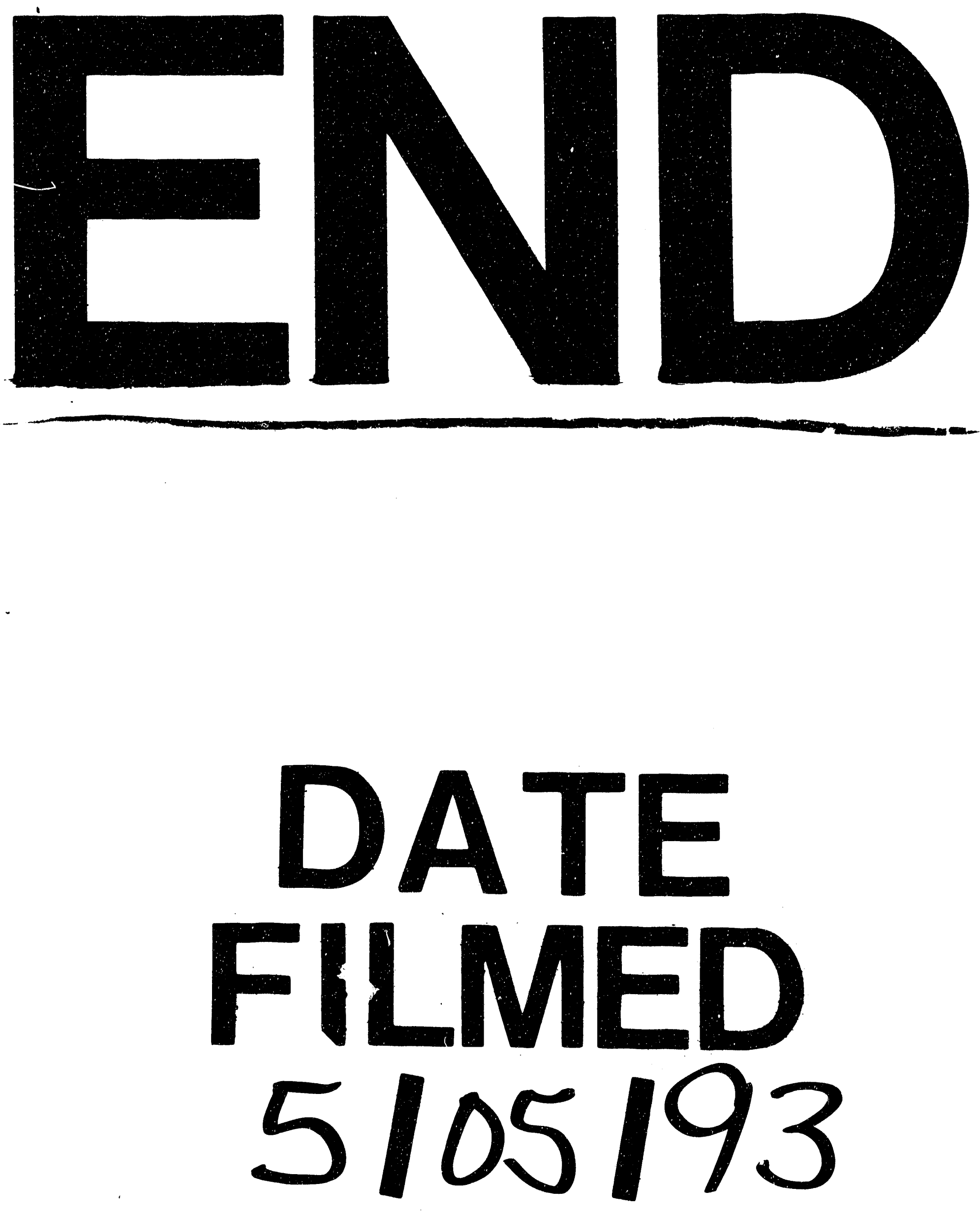
